\title{
Spatial analysis of cases of Tuberculosis with Mental Disorders in São Paulo
}

\author{
Análise espacial dos casos de Tuberculose com Transtornos Mentais em São Paulo \\ Análisis espacial entre casos de tuberculosis y transtornos mentales en São Paulo
}

\section{Luiz Arroyo Henrique Arroyo' ORCID: 0000-0003-3302-0502}

Marcos Augusto Moraes Arcoverde' ORCID: 0000-0001-5104-559X

Josilene Dália Alves' ORCID: 0000-0001-5007-9536

Miguel Fuentealba-Torres ${ }^{1}$ ORCID: 0000-0003-4343-6341

Denisse Cartagena-Ramos' ORCID: 0000-0002-8828-2190

Alessandro Rolim Scholze" ORCID: 0000-0003-4045-3584

Antônio Carlos Vieira Ramos' ORCID: 0000-0002-7862-1355

Ricardo Alexandre Arcêncio' ORCID: 0000-0003-4792-8714

'Universidade de São Paulo, Escola de Enfermagem de Ribeirão Preto.Ribeirão Preto, São Paulo, Brasil.

"Universidade Estadual do Norte do Paraná. Jacarezinho, Paraná, Brasil.

How to cite this article: Arroyo LAH, Arcoverde MAM, Alves JD, Fuentealba-Torres M, Cartagena-Ramos D, Scholze AR, Ramos ACV, Arcêncio RA. Spatial analysis of cases of Tuberculosis with Mental Disorders in São Paulo.

Rev Bras Enferm. [Internet]. 2019;72(3):654-62. doi: http://dx.doi.org/10.1590/0034-7167-2017-0949

Corresponding Author: Luiz Arroyo Henrique Arroyo E-mail: luiz.arroyo@hotmail.com

Submission: 01-29-2018 Approval: 06-16-2018

\section{ABSTRACT}

Objective: To analyze the spatial distribution of Tuberculosis cases with Mental Disorders, identifying factors that determine its occurrence. Method: Ecological study, conducted in the municipalities of São Paulo State. Secondary data were used, with the incidence of Tuberculosis and Mental Disorders as dependent variables in the years 2012 to 2015 and independent variables, socioeconomic, health and income transfer data. The Geographically Weighted Regression was applied in this study. Results: It was observed a distinct distribution between cases of Tuberculosis and Mental Disorders in the municipalities of São Paulo State. Among the explanatory factors, the Primary Care Coverage, population of freedom and income inequality were spatially associated with Mental Illness $\left(R^{2}=0.12\right)$; Alcoholism $\left(R^{2}=0.12\right)$ Illicit Drugs $\left(R^{2}=0.50\right)$ and Smoking $\left(R^{2}=0.50\right)$. Conclusion / Final considerations: The study advances in knowledge by evidencing the spatial distribution of cases of Tuberculosis and Mental Disorders, evidencing the determining factors for its occurrence in São Paulo State.

Descriptors: Mental Health; Mental Disorders; Tuberculosis; Spatial Analysis; Risk factors.

\section{RESUMO}

Objetivo: Analisar a distribuição espacial dos casos de Tuberculose com Transtornos Mentais, identificando fatores que determinam sua ocorrência. Método: Estudo ecológico, conduzido nos municípios do estado de São Paulo. Utilizaram-se dados secundários, tendo-se como variável dependente a incidência da Tuberculose e Transtornos Mentais nos anos de 2012 a 2015 e variáveis independentes, dados socioeconômicos, sanitários e de transferência de renda. Aplicou-se a Geographically Weighted Regression. Resultados: Observou-se uma distribuição distinta entre casos de Tuberculose e Transtornos Mentais nos municípios do estado de São Paulo. Entre os fatores explicativos, a cobertura de Atenção Básica, População Privada de Liberdade e desigualdade de renda estiveram associadas espacialmente com Doença Mental $\left(R^{2}=0,12\right)$; Alcoolismo $\left(R^{2}=0,12\right)$ Drogas llícitas $\left(R^{2}=0,50\right)$ e Tabagismo $\left(R^{2}=0,50\right)$. Conclusão/ Considerações finais: $O$ estudo avança no conhecimento ao evidenciar a distribuição espacial dos casos de Tuberculose e Transtornos Mentais, evidenciando os fatores determinantes para sua ocorrência no estado de São Paulo.

Descritores: Saúde Mental; Transtornos Mentais; Tuberculose; Análise Espacial; Fatores de Risco.

\section{RESUMEN}

Objetivo: Analizar la distribución espacial entre casos de tuberculosis y trastornos mentales, identificando factores que determinan su ocurrencia. Método: Estudio ecológico, conducido en los municipios del estado de São Paulo. Se utilizaron datos secundarios, teniendo como variable dependiente la incidencia de la tuberculosis y trastornos mentales en los años de 2012 a 2015 y variables independientes, datos socioeconómicos, sanitarios y de transferencia de renta. Se aplicó a Geographically Weighted Regression. Resultados: Se observó una distribución distinta entre casos de tuberculosis y trastornos mentales en los municipios del estado de São Paulo. Entre los factores explicativos, la cobertura de Atención Básica, población privada de libertad y desigualdad de ingreso estuvieron asociadas espacialmente con Enfermedad Mental $\left(R^{2}=0,12\right)$; Alcoholismo $\left(R^{2}=0,12\right)$ Drogas Ilícitas $\left(R^{2}=0,50\right)$ y Tabaquismo $\left(R^{2}=\right.$ $0,50)$. Conclusión / Consideraciones finales: El estudio avanza en el conocimiento al evidenciar la distribución espacial de los casos de tuberculosis y trastornos mentales, evidenciando los factores determinantes para su ocurrencia en el estado de São Paulo. Descriptores: Salud Mental; Transtornos Mentales; Tuberculosis; Análisis Espacial; Factores de Riesgo. 
Spatial analysis of cases of Tuberculosis with Mental Disorders in São Paulo Arroyo LAH, Arcoverde MAM, Alves JD, Fuentealba-Torres M, Cartagena-Ramos D, Scholze AR, Ramos ACV, Arcêncio RA.

\section{INTRODUCTION}

Mental Disorders (MD) are considered a pandemic that affect a large part of the world population, being the cause of 10.1 years of life lost due to premature death ${ }^{(1)}$ in Brazil, being the prevalence of these disorders in the general population of $3.6 \%{ }^{(2)}$.

The literature shows that the population with MD presents a greater risk to the development of communicable diseases and related to the poverty, like Tuberculosis (TB) than other health conditions $^{(3)}$. The various MD due to psychoactive substance abuse, such as Illicit Drugs, Alcoholism and Smoking have been being associated with TB illness ${ }^{(4-9)}$. Different explanations are found in the literature for such a cellular association of immunohistochemical reactions, gender differences, behavioral characteristics, lifestyle and work, and unhealthy environments ${ }^{(10)}$.

Among the implications and/or their impact on the diagnosis and treatment of TB, there is the difficulty of adherence to the treatments of both diseases, the greater risk of developing multidrug-resistant $T B$, which means resistance to the two main treatment drugs, increased pharmacological therapy, poor quality of life, catastrophic expenditures and deaths ${ }^{(3,11)}$. Thus, knowing the spatial distribution of these comorbidities is relevant to directing surveillance actions, promoting public policies and increasing the chances of eliminating TB as a public health problem ${ }^{(12)}$.

In the literature, few studies have investigated TB cases with MD in Brazil ${ }^{(13)}$; another knowledge gap is the lack of understanding of its determinants. It is noteworthy that MDs have changed the epidemiological panorama of TB to the point that some countries institute measures directed at populations in this condition ${ }^{(12)}$.

MD reach populations with different demographic, economic, cultural and political characteristics, which makes it relevant to develop studies that can cover such complexity, with a view to a more equitable, efficient and responsible management at local levels, which is undoubtedly extremely relevant for Nursing work in health surveillance.

Geographically Weighted Regression (GWR) ${ }^{(14)}$, which is an exploratory technique designed to identify the spatial nonstationary data, allows the calculation of regression coefficients weighted locally, moving away from their global values and indicating variations in a more adequate and reliable way to each municipality.

In the present study, we focused on MDs classified by the Diagnostic and Statistical Manual of Mental Disorders (DSM-5) (15) as substance-related disorders and addition of drugs such as alcohol, tobacco and illicit drugs; as well as other disorders that encompass an extensive range of psychological and/or mental abnormalities or impairments that affect mood, reasoning, and behavior, which for purposes of discerning them from substance use disorders have been termed Mental IIIness ${ }^{(15)}$.

\section{OBJECTIVE}

This study aims to analyze the spatial distribution between cases of Tuberculosis and Mental Disorders (TB/MD), identifying factors that determine its occurrence in the municipalities of São Paulo.

\section{METHOD}

\section{Ethical aspects}

The present research respected Resolution 466/2012 of the National Health Council (Conselho Nacional de Saúde), as well as national and international laws, however, because it used only secondary data available in public access banks, the research was not forwarded for evaluation by the Research Ethics Committee.

\section{Study design}

This is an ecological study ${ }^{(16)}$, which uses as a unit of analysis the municipalities of São Paulo.

\section{Population}

The population consists of cases of TB, resident in São Paulo State and that presented in the notification the MD: Mental IIIness, Alcoholism, Illicit Drug Use and Smoking.

\section{Variables and data source}

The data were collected through the Sistema de Informação de Agravos de Notificação (SINAN - Information System for Notifiable Diseases) notification records, available on the DATASUS portal (DATASUS is the IT Department of the Brazilian Unified Health System), corresponding to the years 2012 to 2015. The respective study years were chosen because of the availability of the number of cases of MD in SINAN/DATASUS only from the year 2012 and the lack of updating of the data after the year 2015. Due to the use of secondary data, it was not possible to identify patients who were missing out on their behavioral information or in their mental health diagnoses to health professionals who completed the TB notification form in SINAN.

For the descriptive analyzes of the cases, the variables of gender, age and unfavorable outcomes of TB treatment (abandonment and deaths).

The study-dependent variables were composed of the annual incidences of TB with MD comorbidities: Mental Illness, Alcoholism, Illicit Drug Use and Smoking. To meet the objectives, four different explanatory models were constructed, considering each MD. The independent variables were obtained from different public domain databases, taking into account the social determinants of $\mathrm{TB}^{(17)}$.

The Gini Coefficient, collected from the Instituto Brasileiro de Geografia e Estatística (IBGE - Brazilian Institute of Geography and Statistics), reference year 2010 (18); Population Deprived of Liberty (PDL), collected from the Brazilian Department of Penitentiary Administration, referring to the year 2014, gross amount transformed into a proportion of the municipal population, when applicable; Proportion of residents with per capita income up to $1 / 4$ minimum wage (Income $\leq 1 / 4$ ) and Proportion of residents with per capita income between $1 / 4$ and $1 / 2$ minimum wage (Income $1 / 4-1 / 2)$, all collected from IBGE, reference year $2010^{(18)}$. There were coverage indicators of the Programa Bolsa Familia (PBF - Child Benefit Program) and Primary Care (PC), to which they were selected in percentages. The PBF coverage data were collected in the Matriz de Informações Sociais do Ministério do Desenvolvimento Social (Social Information Matrix of the Ministry of Social 
Spatial analysis of cases of Tuberculosis with Mental Disorders in São Paulo Arroyo LAH, Arcoverde MAM, Alves JD, Fuentealba-Torres M, Cartagena-Ramos D, Scholze AR, Ramos ACV, Arcêncio RA.

Development) and PC through the Ministry of Health (TABNET/ DATASUS). Finally, Population Deprived of Liberty (PDL) was collected from the Department of Penitentiary Administration, with reference to 2014, and its value in proportion to the municipal population, when applicable. The choice of PDL variable was due both to the high incidence of TB cases $^{(19)}$ and to the prevalence of Mental Disorders in penal institutions ${ }^{(20)}$.

\section{Data analysis}

An exploratory analysis of the data with the ratio of MD cases in total TB cases in the state was performed. Then, using only TB/ $\mathrm{MD}$ cases, the proportions of these cases were found between sex, age ( $\leq 14$ years, $15-59$ years and $\geq 60$ years) and unfavorable outcomes of TB treatment (abandonment and deaths).

The average annual incidence (between the years 2012-2015) was standardized by sex and age of each comorbidity (Tuberculosis and Mental Illness - TB/MI, Tuberculosis and Alcoholism -TB/ $A L$, Tuberculosis and Illicit Drug Use - TB/ID, Tuberculosis and Smoking - TB/SMO) for each municipality of São Paulo. Each comorbidity was tested for the independent variables, applying linear multiple regression (OLS - Ordinary Least Squares) by software $R$ version 3.4.2.

These variables were analyzed for multicolumniarity through Variance Inflation Factor (VIF), with values below 10 being considered adequate ${ }^{(21)}$. The best model was defined by AIC (Akaike Information Criterion) values. In addition, the models were analyzed according to ANOVA one way, Wald and Koenker statistics.

For the variables that remained in the OLS model, Geographically Weighted Regression (GWR) was applied through ArcGis software version 10.5.1. The Moran Index (I) of the residues of the resulting GWR models was evaluated for spatial dependence. Thematic maps were built in ArcGis software version 10.5.1; for all tests, type l error was set at $5 \%(p<0.05)$ as statistically significant.

\section{RESULTS}

There were 78,904 reported cases of TB between 2012 and 2015, with 1,299 (1.56\%) presenting Mental Illness, 13,476 (17,08\%) Alcoholism, 9,631 (12.21\%) Smoking and 11,765 (14.91\%) cases of Illicit Drugs Use.

Table 1 shows the main characteristics of the cases enrolled for the study, and in all comorbidities, there was a predominance of males. In relation to the age group, comorbidities were predominant at ages between 15 and 59 years. Regarding the unfavorable outcomes, abandonment was higher for TB/ID (26.5\%) and lower for TB/MI (9.52\%). For the deaths, both TB/AL and TB/MI had 5.9\% of their cases with this outcome, showing larger proportions when compared to the other TB/MD.

The spatial distribution of incidences is shown in Figures 1 to 4; according to them, it can be observed that both TB/AL and $\mathrm{TB} / \mathrm{SMO}$ presented a greater number of municipalities with nonzero incidences; in contrast to TB/MI, which was the one with the highest number of municipalities with zero incidence.

Each TB/MD comorbidity presented different explanatory variables, and for TB/AL: PDL $\beta=0.176(p<0.01)$ and PC Coverage $\beta=-0.025(p<0,01)$ with VIF of 1.00 ; for TB/MI: PDL $\beta=0.039$ $(p<0,01), P I B \beta=0.001(p<0.01), 1 / 4-1 / 2$ Income $\beta=0.043(p<0.01)$, $\leq 1 / 4$ Income $\beta=-0.061(p=0.03)$ and $P C$ Coverage $\beta=-0.005(p=0.03)$ with VIF ranging from 1.0 to 5.4; for TB/ID: $P D L=0.524(p<0.01)$, $1 / 4-1 / 2$ Income $\beta=0.058(p<0.01)$ and $P C$ Coverage $\beta=-0.044(p=0.02)$ with VIF of 1.00; and for TB/SMO: PDL $\beta=0.520(p<0.01)$ and Gini Coefficient $\beta=4.459(p=0.01)$ with VIF of 1.00 .

No redundancy was indicated between the explanatory variables (VIF value of the variables less than 10) and their final OLS models could explain between $6 \%$ and $28 \%\left(R^{2}\right)$ of the variation of the rates of comorbidities studied, with AIC between 3965.40 and 4202, 28. In addition, ANOVA and Wald statistics confirmed these associations. The Koenker statistic was statistically significant in all TB/MD models, confirming their adequacy and relevance.

Table 1 - Characteristics among cases of Tuberculosis and Mental Disorders (2012 - 2015)

\begin{tabular}{|c|c|c|c|c|}
\hline Characteristics of Tuberculosis/Mental Disorders cases & $\begin{array}{c}\text { Tuberculosis/ } \\
\text { Mental Illness } \\
\text { n(\%) }\end{array}$ & $\begin{array}{c}\text { Tuberculosis/ } \\
\text { Alcoholism } \\
\text { n(\%) }\end{array}$ & $\begin{array}{c}\text { Tuberculosis/ } \\
\text { Smoking } \\
\text { n(\%) }\end{array}$ & $\begin{array}{c}\text { Tuberculosis/ } \\
\text { Illicit Drugs } \\
\text { n(\%) }\end{array}$ \\
\hline Total of cases & 1,229 & 13,476 & 9,631 & 11,765 \\
\hline \multicolumn{5}{|l|}{ Sex } \\
\hline Male & $848(69)$ & $12088(89.70)$ & $7796(80.95)$ & $9953(84.60)$ \\
\hline Female & $381(31)$ & $1388(10.30)$ & $1835(19.05)$ & $1812(15.40)$ \\
\hline \multicolumn{5}{|l|}{ Age } \\
\hline Up to 14 & $19(1.55)$ & $20(0.15)$ & $21(0.22)$ & $23(0.20)$ \\
\hline From 15 to 59 & $1062(86.41)$ & $12318(91.41)$ & $8480(88.05)$ & $11649(99.01)$ \\
\hline 60 or above & $146(11.88)$ & $1124(8.34)$ & $1126(11.69)$ & $84(0.71)$ \\
\hline Ignored & $2(0.16)$ & $14(0.10)$ & $04(0.04)$ & $9(0.08)$ \\
\hline \multicolumn{5}{|l|}{ Unfavorable outcomes of tuberculosis treatments } \\
\hline Abandonment & $117(9.52)$ & $2500(18.55)$ & $1156(12.00)$ & $3117(26.49)$ \\
\hline Death* & $72(5.86)$ & $790(5.86)$ & $401(4.16)$ & $325(2.76)$ \\
\hline
\end{tabular}


The results from the application of GWR are shown in Figures 1 to 4; in this analysis, the variables that were presented as the best models for each comorbidity, according to the lowest AIC values in the linear models.

It can be observed that GWR (Figures 1 to 4) resulted in significantly better models in all TB/MD comorbidities, increasing the ability to explain their variation, with $\mathrm{R}^{2}$ adjusted between $12 \%$ and $50 \%$. The percentage of $R^{2}$ that was increased, compared to the linear model, indicates the importance of space in the modeling and in the occurrence of the studied events.

When analyzing the spatial autocorrelation of the residues of the GWR models, there was a randomness in the distribution of these with Moran Index values of 0.02 and $z$ value of $1.37(p=$ 0.1 ) for $T B / A L,-0.02$ and $z$-value of -1.31 $(p=0.2)$ in TB/SMO, -0.02 and $z$ value of $-1.09(p=0.2)$ for TB/ID and $-0,04$ and $z$-value of $-2.38(p=0.1)$ in TB/MI.

It is important to emphasize that the PDL presented a strong relation with the TB/MD comorbidities, being that the majority was positive, meaning that the increase in PDL results in an increase in the incidence. The PDL association was higher mainly in the southern regions of the state for TB/ $A L, T B / S M O$ and TB/ID comorbidities, whereas for TB/Ml it was present in almost all municipalities of São Paulo.

In the case of PC Coverage, it had an inverse relationship with the comorbidities, which means that with the increase of this variable there is possibly a reduction of $\mathrm{TB}$ with $\mathrm{MD}$. This is most evident in municipalities of the south and interior of the state regarding $\mathrm{TB} /$ AL and TB/ID comorbidities, and for TB/ $\mathrm{Ml}$ their influence was greater from the interior to the West of the state.

TB/MI comorbidity was positively associated with municipalities where there is a predominance of domiciles with low income, and this is clearly observed with more intensity in the Northeast and Southeast of the state. The TB/ID comorbidity, the low income had a strong relation in almost all the municipalities, being that in the Northwest region this is more visible by the maps.
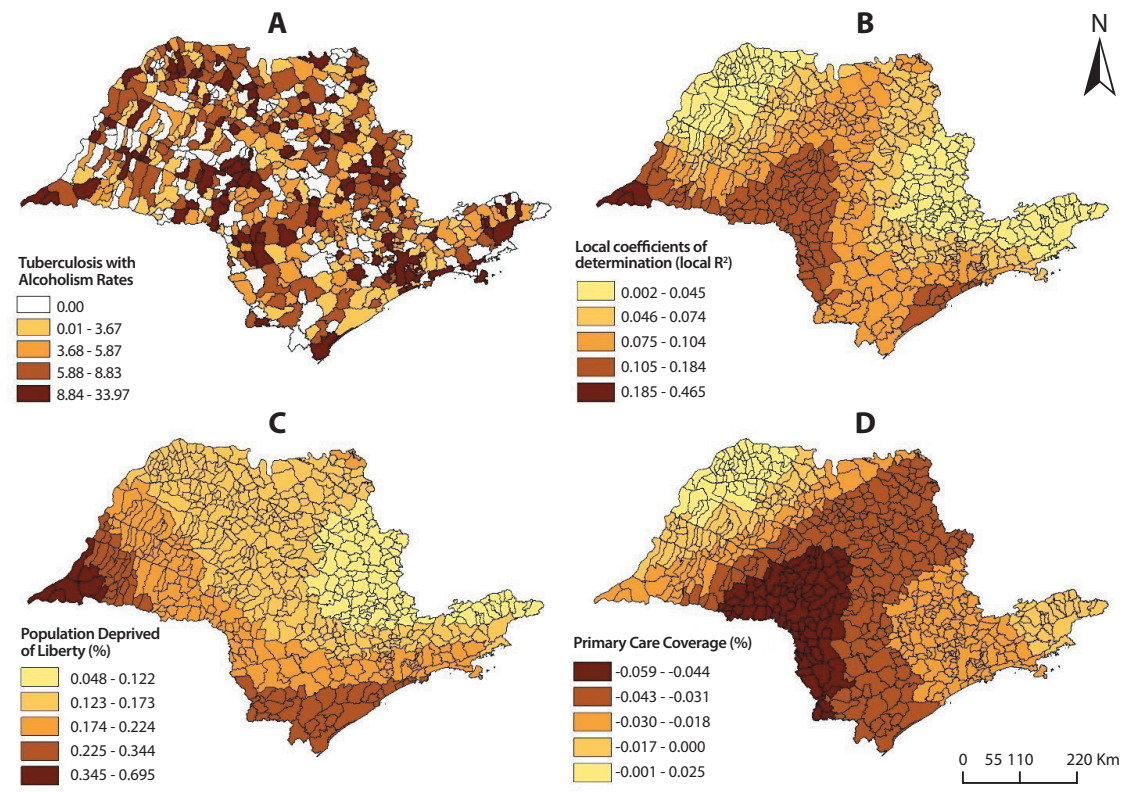

Note: A: Tuberculosis with Alcoholism Rates (TB/AL); B: Local coefficients of determination; C: Local coefficients of the Population De prived of Liberty $(P D L)$ variable; $D$ : Local coefficients of the Primary Care Coverage $(P C)$ variable. Linear Model TB/AL: AIC $=3965.40 ; R^{2}$ $=0.06 ; R^{2}$ adjusted $=0.05 ;$ ANOVA= $21.1(p<0.01) ;$ Wald $=27.31(p<0.01) ;$ Koenker= $7.16(p=0.02)$. Model TB/AL GWR: AIC $=3950.18$; $R^{2}=0.12 ; R^{2}$ adjusted $=0.09$.

Figure 1 - Spatial distribution of incidence, local coefficients of explanatory variables and local coefficient of determinants of the Geographically Weighted Regression of Tuberculosis with Alcoholism cases - SP, 2012 - 2015

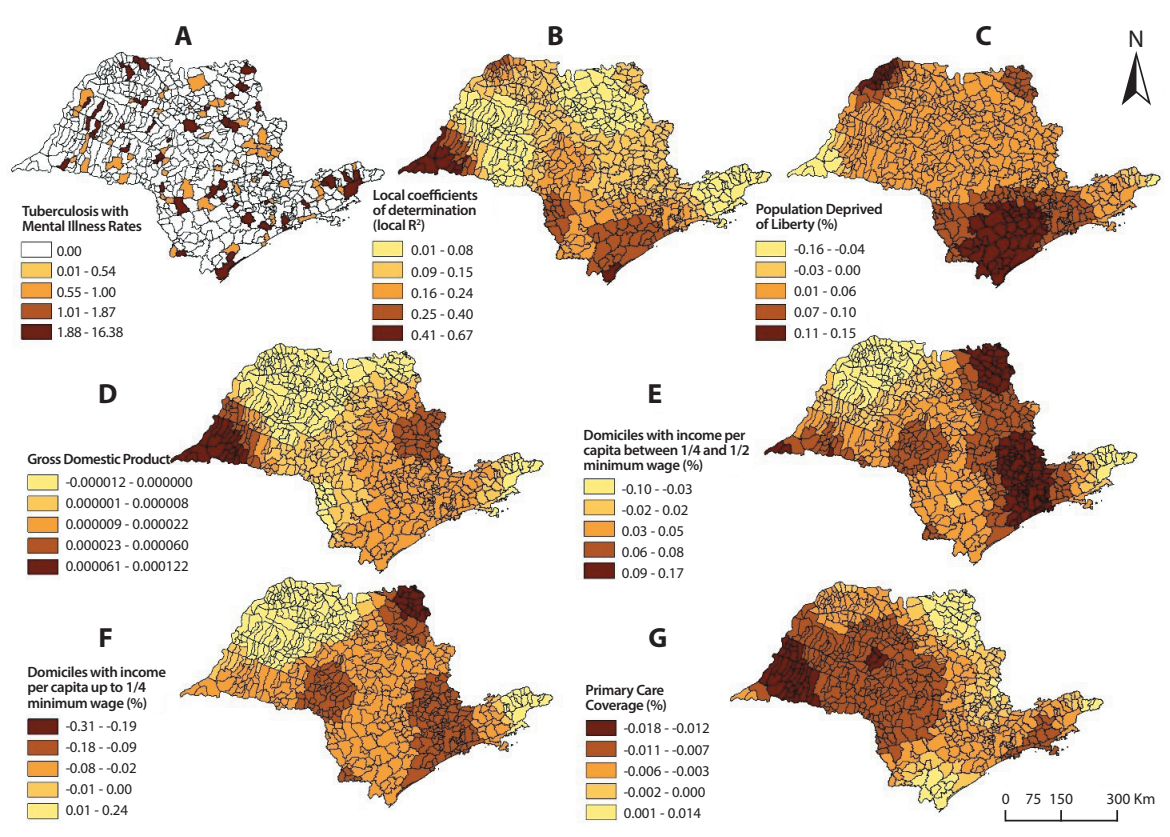

Note: A: Tuberculosis with Mental Illness Rates (TB/MI); B: Local coefficients of determination C: Local coefficients of the Population Deprived of Liberty (PDL) variable; D: Local coefficients of the variable Gross Domestic Product (GDP); E: Local coefficients of the Domiciles with income per capita between $1 / 4$ and $1 / 2$ minimum wage $(1 / 4-1 / 2$ Income) variable; F: Local coefficients of the Domiciles with income per capita up to $1 / 4$ minimum wage (Income $\leq 1 / 4)$ variable; G: Local coefficients of the $(P C)$ variable. Linear Model TB/MI: $A I C=2277.07 ; R^{2}=0.07 ; R^{2}$ adjusted $=0.06 ;$ ANOVA= $10.2(p<0.01) ;$ Wald= $20.68(p<0.01) ;$ Koenker $=11.16(p=0.04)$. Model TB/MI GWR: $A I C=2260.93 ; R^{2}=0.22 ; R^{2}$ adjusted $=0.13$.

Figure 2 - Spatial distribution of the incidence of local coefficients of the explanatory variables and coefficients of determination of the Geographically Weighted Regression of Tuberculosis with Mental Illness - SP, 2012 - 2015 


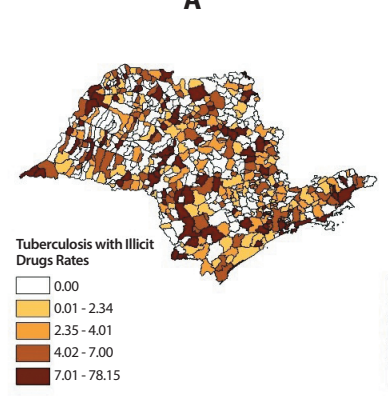

D

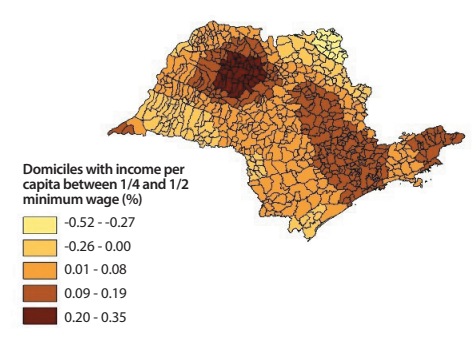

B

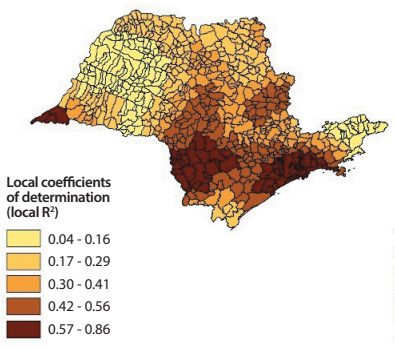

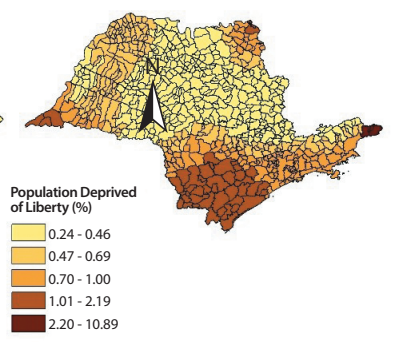

E

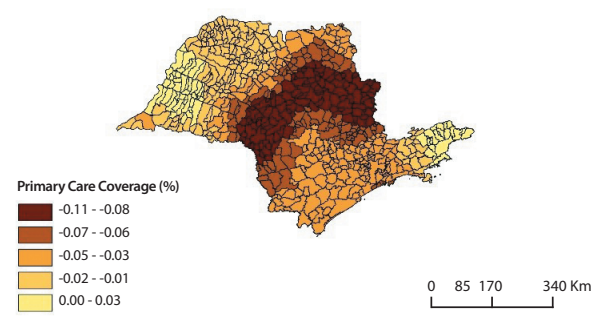

Note: A: Tuberculosis with Illicit Drugs Rates (TB/ID); B: Local coefficients of determination; C: Local coefficients of the Population Deprived of Liberty (PDL) variable; D: Local coefficients of the Domicile with income per capita between $11 / 4$ and $1 / 2$ minimum wage $\left(1 / 4-1 / 2\right.$ Income); E: Local coefficients of the Primary Care Coverage variable (PC). Linear Model TB/ID: AIC $=4161.39 ; R^{2}=0.28 ; R^{2}$ adjusted $=0.28 ; A N O V A=84.7(p<0.01) ;$ Wald $=74.90(p<0.01)$; Koenker $=13.4(p<0.01)$. Model TB/ID GWR: $A I C=4037.10 ; R^{2}=0.50 ;$ Adjusted $R^{2}=0.44$.

Figure 3 - Spatial distribution of incidence, local coefficients of explanatory variables and coefficients of determination of the Geographically Weighted Regression of Tuberculosis with Illicit Drug cases - SP, $2012-2015$

A

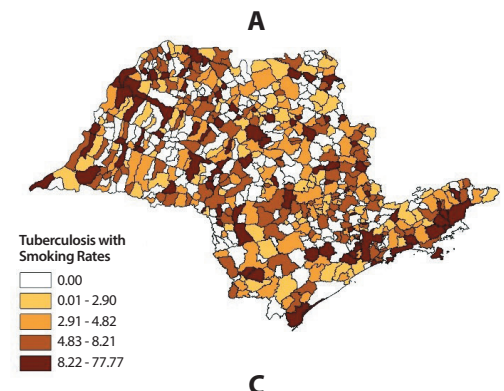

C

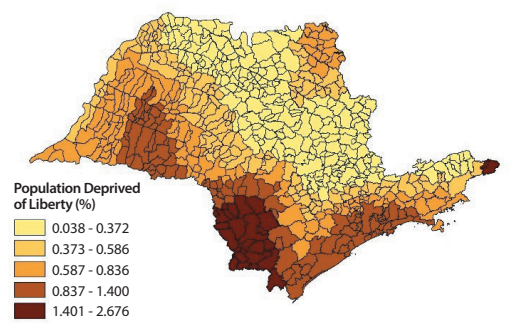

B

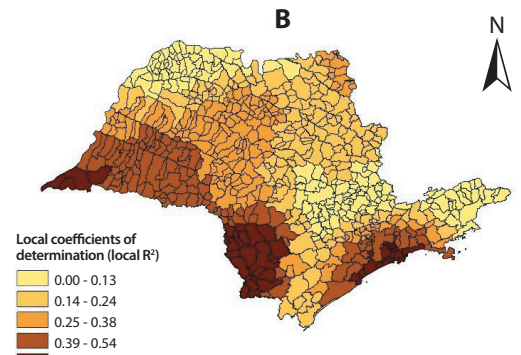

D

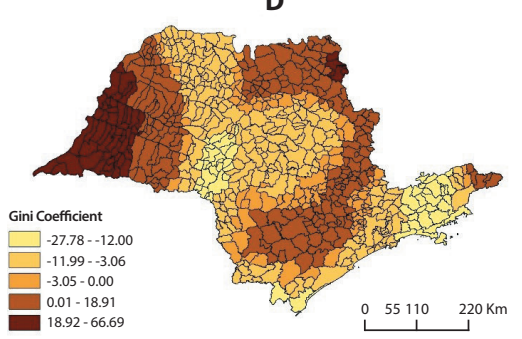

Nota: A: Tuberculosis with Smoking Rates (TB/SMO); B: Local coefficients of determination; C: Local coefficients of the Population Deprived of Liberty (PDL) variable; D: Local coefficients of the Gini Coefficient variable. Linear Model TB/ $S M O: A I C=4202.28 ; R^{2}=0.25 ; R^{2}$ adjusted $=0.25 ;$ ANOVA $=110.8(p<0.01) ;$ Wald $=13.92(p<0.01) ;$ Koenker $=174.11(p$ $<0.01)$. Model TB/SMO GWR: $A / C=4094.59 ; R^{2}=0.44 ; R^{2}$ adjusted $=0.39$.

Figure 4 - Spatial distribution of the incidence of local coefficients of the explanatory variables and coefficients of determination of the Geographically Weighted Regression of Tuberculosis with Smoking - SP, $2012-2015$

A positive relationship was observed between the Gini Coefficient and the incidence of TB/SMO, confirming that inequality is an important determinant for TB/MD cases.

\section{DISCUSSION}

The study sought to analyze the spatial distribution of TB incidence with the presence of MD and its determinants. Through the descriptive analysis, one can identify that the proportion of TB cases associated with Alcoholism, Smoking, Mental IIIness and Illegal Drugs is relevant, with a deformed distribution between the regions of the state and with different determinants. There were low income, social inequality (expressed by the Gini Coefficient), PC Coverage and the presence of prisons in municipalities.

The originality of the present study lies in the fact of showing the picture of the incidence of these morbidities in São Paulo State, where managers and workers must redouble their attention and manage to these conditions in an integrated and non-fragmented way.

It should be noted that approximately half of the TB cases in São Paulo presented at least one of the MD analyzed, which indicates the strong relation of these, as also reported in a study conducted in Pakistan ${ }^{(22)}$.

The literature shows evidence of common risk factors between TB and MD, and also allows the progression of latent TB infection to the active form of the disease as a result of the immunological suppression caused by smoking, caloric-protein malnutrition and other comorbidities. Almost $1 / 3$ of the world's population is estimated to be infected with Mycobacterium tuberculosis and the number of people with MD is increasing, and TB is a predictor of TB disease, if not managed properly and in an integrated, sensitive approach and directed, there may be a loss of disease control leading to the suffering of MD patients and their families ${ }^{(3)}$.

There is also the question of their own social determinants and inequity, such as street people, shelter dwellers, unhealthy homes, subhuman working conditions and impaired self-care, which reinforces the relationship between $\mathrm{TB}$ and $\mathrm{MD}^{(3)}$.

A finding of the study is that classically MD have a higher prevalence in women ${ }^{(23)}$, however, a predominance of TB and MD has been observed in men, which is already known for $\mathrm{TB}^{(24)}$. The age of the cases also corresponds to the common TB profile ${ }^{(1,25)}$, but it does not deviate from the classic profile of MD.

It was verified that the abandonment of the TB/MD treatments ranged from $9.52 \%$ to $26.49 \%$, and if a parallel of these values 
is drawn with the state average of abandoned TB treatment, which has a value of $10.2 \%$ for the year $2015^{(26)}, \mathrm{TB} / \mathrm{AL}, \mathrm{TB} / \mathrm{SMO}$ and TB/ID comorbidities presented higher abandonment rates. The literature shows weaknesses in the attention given to the association of TB/MD during treatment, which may be related to the greater number of abandonments observed ${ }^{(11)}$.

Unsuitable treatment can lead to a reduction in patients' quality of life, worsening of MD, a greater chance of TB resistant form, and a higher frequency of deaths ${ }^{(27)}$. Regarding the death itself, it was also higher than the state average of $3.2 \%{ }^{(28)}$ in TB/ $\mathrm{MI}, \mathrm{TB} / \mathrm{AL}$ and TB/SMO.

It should be noted that the high incidence among neighboring municipalities emphasize the importance of spatially understanding these diseases and which determinants of a certain area can explain the phenomenon in that region and not in another region; which makes some populations more vulnerable. The results obtained from the GWR application helped to elucidate such complexity.

The PDL was related to all cases of TB with MD, although its impact is different among municipalities. It is known that the prison units contain high prevalence of $\mathrm{TB}$ and $\mathrm{MD}^{(19-20)}$, an aggravating factor is that a large portion of the PDL experiences a lack of adequate follow-up during treatments, as well as cultural, organizational and geographical barriers to the provision of care or scheduling difficulties for consultations together with the unavailability of transport of individuals to health services ${ }^{(29)}$. This reinforces the need for changes in the living conditions of prison institutions, avoiding crowding of individuals, improving nutritional and infrastructure conditions in cell ventilation. In addition, it is important to develop health policies that are particularly directed at these individuals, implementing comprehensive care through context-sensitive Primary Care services linked to community services and the inclusion of professionals trained and sensitive to the demands derived from incarceration ${ }^{(30)}$.

The social conditions were associated with TB/SMO, TB/MI and TB/ID comorbidities, being this through low income variables or inequality indicators of income distribution. Kondo (2012) (31) explains that income inequalities lead to two paths that culminate in the emergence of diseases, being a material and a psychosocial path. The increase in income inequality leads people to a sense of relative deprivation, which results in frustration, shame, stress, health risk behaviors and even the emergence of $\mathrm{MD}^{(32-33)}$.

Authors corroborate this finding by showing that men in worse income conditions were at greater risk for developing excessive consumption of tobacco. In the case of alcohol abuse, the evidence is limited on its relation to income inequality ${ }^{(34)}$, however there are indications that alcoholism falls most heavily on low-income people depending on cultural factors and consumption practices ${ }^{(35)}$.

The same occurs in the case of Illicit Drugs, which, despite being commonly related to the conditions of social inequality, their association is controversial and requires greater understanding, possibly due to the variety of substances to which they may be consumed or because one does not understand exactly how this relationship behaves in different periods of life ${ }^{(36)}$.

It is highlighted that income inequalities are a risk factor for the emergence of TB, recognized in literature ${ }^{(37)}$. And from the results found in this study, they can also converge to make municipalities vulnerable to TB/MD.

PC Coverage was associated with TB/AL, TB/MI, TB/ID comorbidities, being predominantly considered to be protective for events in the municipalities of São Paulo. In agreement with the findings, studies indicate that PC interventions present good cost-effective results in reducing alcohol consumption ${ }^{(38)}$, in which it is highlighted that PC professionals can contribute directly to the actions of reception, counseling and referral of these patients to specialized services ${ }^{(39)}$.

In addition, in the context of MD, PC is essential to improve patient care, especially reducing the barriers imposed by stigma that impact the search for help in health services ${ }^{(40)}$. The study highlights the interventions needed to increase the access of these patients to services, focusing on community interventions that reduce stereotypes or feelings of social rejection and discrimination $^{(40)}$, which become more potent when associated with MD.

Experiences evidenced in the literature, demonstrate successful actions of PC in prevention in relation to illicit drug use, especially in school environments ${ }^{(41)}$. Thus, PC and its professionals play an important role in the reduction of TB/MD cases, mainly through the implementation of strategies to improve access and diagnosis of these patients through active search ${ }^{(42)}$ and coping with bottlenecks affect the follow-up actions of the cases, such as the absence of a link between professionals and patients and the difficulty of receiving this population in the health units ${ }^{(43)}$.

The association between TB/MD represents an opportunity for advancement both for the diagnosis and for the treatment of both comorbidities, while the existence of municipalities with high TB burden may represent the need for specific activities to search for and prevent MD and health promotion.

It is important to emphasize that, even though it is not the subject of the study, the diagnosis of TB should alert to mental health disorders in patients, considering the association of these diseases in São Paulo State and the risk of treatment failure.

The results point to changes in the care model in the face of the epidemiological panorama found in the state as of the integration between Mental Health Programs and TB Control Programs, and to undertake synergistic actions to generate interprofessional and intersectoral strategies depending on population characteristics and burden of diseases in the respective municipalities of São Paulo(44).

The issue of the use of Illicit Drugs among TB patients is an important point when defining strategies that aim to eliminate the disease in the national setting, so new tools and/or tools can be introduced into the practice of Directly Observed Treatment (DOT) itself, in order to guarantee adherence to the treatment and reduction of damages due to the abusive use of these drugs. Most of the DOT programs in Brazil are developed by nurses, so the comorbidities are placed in the daily life of these professionals every day. Thus, the study contributes to the advancement of this professional in the management of these conditions.

The impact of MDs on the chain of TB progression (from infection to cure) is clear from the study, so nurses and other health professionals should be sensitive to the use of more appropriate tools and technologies to promote equity, dignity, quality life and respect for people under this condition. It is worth mentioning 
that due to the stigma existing in both TB and MD, it results in a double burden of stigma, which often causes patients to abandon their treatment and have worse prognoses. An inclusive and emancipatory approach may result in important changes in the horizon of patients under these conditions.

\section{Study limitations}

The study has limitations, while the use of secondary data may lead to typos and/or non-updated data of the epidemiological reality of the state. In addition, patients diagnosed with TB may not know the MD they own, or even omit them by stigma. The design of the study does not allow controlling such types of biases.

\section{Contributions for the sectors of Nursing, Health or Public Policy}

The study advances knowledge, evidencing the reality of TB/ MD comorbidities and the main determinants that impact these conditions in the municipalities of São Paulo. The scope of such results was made possible by the local analysis used by the GWR technique, showing the potential of this tool for the study of regions with heterogeneous characteristics, such as São Paulo State. Therefore, research contributes to public policies and to the country, as it shows an important epidemiological reality and is a potential obstacle to the goal of ending TB. The importance of nurses and health professionals who are aware and capable of handling both conditions, with a view to patient-centered treatment, under penalty of abandonment, more severe cases and putting at risk collective health and quality of population.

\section{CONCLUSION / FINAL CONSIDERATIONS}

TB with the presence of MD presented a serious public health problem that could lead to worse outcomes in TB treatments and worsening of MDs. It was observed that each studied comorbidity has different determinants, being that individuals deprived of freedom or in conditions of income inequality are the most defining of these conditions. It is important to highlight that PC Coverage has proved to be a potential protective factor for such conditions, which may be an important mechanism in the fight against TB and in the quality of life of patients with MD. Knowing this reality and the way these diseases spread in space can guide public policies and more directive interventions, modifying the current setting of TB and controlling its association with other important morbidities with MD.

\section{FUNDING}

This study was financed by the Conselho Nacional de Desenvolvimento Científico e Tecnológico (CNPq-National Council for Scientific and Technological Development) - Process 141913/20177; Process 305236/2015-6. Fundação de Amparoà Pesquisa do Estado de São Paulo (FAPESP - São Paulo Research Foundation) - Process 2017/11040-4.

\section{REFERENCES}

1. Bonadiman CSC, Passos VMA, Mooney M, Naghavi M, Melo APS. The Burden of disease attributable to mental and substance use disorders in Brazil: global burden of disease study, 1990 and 2015. Rev Bras Epidemiol [Internet]. 2017 [cited 2018 May 02];20(Suppl 1):191-204. Available from: http://dx.doi.org/10.1590/1980-5497201700050016

2. Andrade LH, Wang Y-P, Andreoni S, Silveira CM, Alexandrino-Silva C, Siu ER, et al. Mental disorders in megacities: findings from the São Paulo megacity mental health survey, Brazil. PLoS ONE [Internet]. 2012 [cited 2017 Dec 15];7(2):e31879. Available from: https://doi.org/10.1371/ journal.pone.0031879

3. Doherty AM, Kelly J, McDonald C, O'Dywer AM, Keane J, Cooney J. A review of the interplay between tuberculosis and mental health. Gen Hosp Psychiatry [Internet]. 2013 [cited 2017 Dec 15];35(4):398-406. Available from: https://foi.org/10.1016/j.genhosppsych.2013.03.018

4. Hernández Sarmiento JM, Correa N, Correa M, Franco JG, Alvarez M, Ramírez C, et al. Tuberculosis among homeless population from Medellín, Colombia: associated mental disorders and socio-demographic characteristics. J Immigr Minor Health [Internet]. 2013 [cited 2017 Dec 15];15(4):693-9. Available from: https://doi.org/10.1007/s10903-013-9776-x

5. Nahas MA, Melo APS, Cournos F, Mckinnon K, Wainberg M, Guimarães MDC. Recent illicit drug use among psychiatric patients in Brazil: a national representative study. Rev Saude Publica [Internet]. 2017 [cited 2017 Dec 18];51:74. Available from: https://doi.org/10.11606/ S1518-8787.2017051006543

6. Kuznetsov VN, Shelygin KV, Grjibovski AM, Mariandyshev AO, Johansson E, Bjune GA. Incidence of tuberculosis and associations with indicators of alcohol consumption in three regions of Northwest Russia in 1975-2009: a time-series analysis. J Environ Public Health [Internet]. 2013 [cited 2017 Dec 15];2013:693963. Available from: https://doi.org/10.1155/2013/693963

7. Imtiaz S, Shield KD, Roerecke M, Samokhvalov AV, Lönnroth K, Rehm J. Alcohol consumption as a risk factor for tuberculosis: meta-analyses and burden of disease. Eur Respir J [Internet]. 2017 [cited 2017 Dec 15];50(1):1700216. Available from: https://doi. org/10.1183/13993003.00216-2017

8. Cavanaugh JS, Powell K, Renwick OJ, Davis KL, Hilliard A, Benjamin C, et al. An outbreak of tuberculosis among adults with mental illness. Am J Psychiatry [Internet]. 2012 [cited 201716 Dec];169(6):569-75. Available from: http://doi.org/10.1176/appi.ajp.2011.11081311

9. Przybylski G, Nowakowska-Arendt A, Pilaczyńska-Cemel M, Gołda R. [10 years comparative clinico-epidemiological analysis of smoking and alcohol consumption in TB patients (Myc. Tuberculosis) and with mycobacteriosis (Myc. Kansas]. Przegl Lek [Internet]. 2014 [cited 2017 Dec 15];71(11):576-80. Available from: http://europepmc.org/abstract/med/25799847 Polish. 
10. Aldridge RW, Story A, Hwang SW, Nordentoft M, Luchenski SA, Hartwell G, et al. Morbidity and mortality in homeless individuals, prisoners, sex workers, and individuals with substance use disorders in high-income countries: a systematic review and meta-analysis. Lancet [Internet]. 2017 [cited 2017 Dec 18];391(10117):241-50. Available from: http://doi.org/10.1016/S0140-6736(17)31869-X

11. Pachi A, Bratis D, Moussas G, Tselebis A. Psychiatric morbidity and other factors affecting treatment adherence in pulmonary tuberculosis patients. Tuberc Res Treat [Internet]. 2013 [cited 2017 Dec 15];2013:489865. Available from: http://doi.org/10.1155/2013/489865

12. Walker IF, Baral SC, Wei X, Huque R, Khan A, Walley J, et al. Multidrug-resistant tuberculosis treatment programmes insufficiently consider comorbid mental disorders. Int J Tuberc Lung Dis [Internet]. 2017 [cited 2017 Dec 15];21(6):603-9. Available from: http://doi.org/10.5588/ ijtld.17.0135

13. Araújo GS, Pereira SM, Santos DN. Revisão sobre tuberculose e transtornos mentais comuns. Rev Eletr Gestão Saúde [Internet]. 2014 [cited 2017 Dec 15];5(2):716-26. Available from: http://www.convibra.com.br/upload/paper/2013/67/2013_67_7625.pdf

14. Fotheringham AS, Brunsdon C, Charlton ME. Geographically Weighted Regression: the analysis of spatially varying relationships. New York: Wiley; 2002.

15. American Pyschiatric Association. Manual diagnóstico e estatístico de transtornos mentais: DSM-5. 5ed. Porto Alegre: Artmed; 2014.

16. Morgenstern H. Ecologic Studies. In: Rothman KJ, Greenland S, Lash TL, editors. Modern Epidemiology. 3th ed. Philadelphia: Lippincot Williams \& Wilkins; 2008. p.512-31.

17. Hargreaves JR, Boccia D, Evans CA, Adato M, Petticrew M, Porter JDH. The social determinants of tuberculosis: from evidence to action. Am J Public Health [Internet]. 2011 [cited 2017 Dec 18];101(4):654-62. Available from: http://dx.doi.org/10.2105/AJPH.2010.199505

18. IBGE: Instituto Brasileiro de Geografia e Estatística. [Internet]. Rio de Janeiro: IBGE; 2010. Base de informações do Censo Demográfico 2010: Resultados do Universo por setor censitário [cited 2017 Dec 18]; [about 1 screen]. Available from: http://www.ipea.gov.br/redeipea/images/ pdfs/base_de_informacoess_por_setor_censitario_universo_censo_2010.pdf

19. Sánchez AR, Larouzé $B$, Diuana V. Tuberculosis control in Brazilian prisons: new approaches to an old problem. Cad Saude Publica [Internte]. 2010 [cited 2017 Dec 15];26(5):850-1. Available from: http://dx.doi.org/10.1590/S0102-311X2010000500001

20. Vargas F, Hoffmeister FX, Prates PF, Vasconcellos SJL [Depression, anxiety and psychopathy: a correlational study with persons deprived of liberty]. J Bras Psiquiatr [Internet]. 2015 [cited 2017 Dec 15];64(4): 266-71. Available from: http://doi.org/10.1590/0047-2085000000088 Portuguese.

21. Montgomery DC, Peck EA, Vining GG. Intoduction to linear regression analysis. 4th ed. New Jersey: John Wiley \& Sons; 2013.

22. Aamir S, Aisha. Co-morbid anxiety and depression among pulmonary tuberculosis patients. J Coll Physicians Surg Pak [Internet]. 2010 [cited 2017 Dec 15];20(10):703-4. Available from: http://doi.org/10.2010/JCPSP.703704

23. Gonçalves DA, Mari JJ, Bower P, Gask L, Dowrick C, Tófoli LF, et al. Brazilian multicentre study of common mental disorders in primary care: rates and related social and demographic factors. Cad Saúde Pública [Internet]. 2014 [cited 2017 Dec 15];30(3):623-32. Available from: http://dx.doi.org/10.1590/0102-311X00158412

24. Nhamoyebonde S, Leslie A. Biological differences between the sexes and susceptibility to tuberculosis. J Infect Dis [Internet]. 2014 [cited 2017 Dec 15];209 Suppl 3:S100-6. Available from: http://doi.org/10.1093/infdis/jiu147

25. Araújo GS, Pereira SM, Santos DN, Marinho JM, Rodrigues LC, Barreto ML. Common mental disorders associated with tuberculosis: a matched case-control study. PLoS ONE [Internet]. 2014 [cited 2017 Dec 15]; 9(6):e99551. Available from: http://doi.org/10.1371/journal. pone.0099551

26. Ministério da Saúde (BR), Secretaria de Vigilância em Saúde. Boletim Epidemiológico [Internet]. Brasília (DF): Ministério da Saúde; 2017[cited 2017 Dec 15]. Available from: http://portalarquivos.saude.gov.br/images/pdf/2017/marco/23/2017-V-48-N-8-Indicadores-priorit--rios-parao-monitoramento-do-Plano-Nacional-pelo-Fim-da-Tuberculose-como-Problema-de-Sa--de-P--blica-no-Brasil.pdf

27. Deribew A, Deribe K, Reda AA, Tesfaye M, Hailmichael Y, Maja T, et al. Change in quality of life: a follow up study among patients with HIV infection with and without TB in Ethiopia. BMC Public Health [Internet]. 2013 [cited 2017 Dec 15];13:408. Available from: http://doi. org/10.1186/1471-2458-13-408

28. DATASUS [Internet]. Brasília: Ministério da Saúde; 2019. Sistema de Informação de Agravos de Notificação. Casos confirmados de tuberculose por Situação Encerra, segundo Ano Diagnóstico, Período: 2012-2015 [citation 2017 Nov 28]; [about 2 screens] Available from: http://tabnet.datasus.gov.br/cgi/tabcgi.exe?sinannet/cnv/tubercSP.def

29. Costa NR, Silva PRF. Mental health care for Brazilian juvenile offenders. Ciênc Saúde Coletiva [Internet]. 2017 [cited 2017 Dec 15];22(5):146778. Available from: https://doi.org/10.1590/1413-81232017225.33562016

30. Telisinghe L, Charalambous S, Topp SM, Herce ME, Hoffmann CJ, Barron P, et al. HIV and tuberculosis in prisons in sub-Saharan Africa. Lancet [Internet]. 2016 [cited 2017 May 18];388(10050): 1215-27. Available from: https://doi.org/10.1016/S0140-6736(16)30578-5

31. Kondo N, van Dam RM, Sembajwe G, Subramanian SV, Kawachi I, Yamagata Z. Income inequality and health: the role of population size, inequality threshold, period effects and lag effects. J Epidemiol Community Health [Internet]. 2012 [cited 2017 Dec 16];66(6):e11. Available from: https://doi.org/10.1136/jech-2011-200321

32. Rojas-García A, Ruiz-Perez I, Rodríguez-Barranco M, Gonçalves Bradley DC, Pastor-Moreno G, Ricci-Cabello I. Healthcare interventions for depression in low socioeconomic status populations: a systematic review and meta-analysis. Clin Psychol Ver [Internet]. 2015 [cited 2017 Dec 16];38:65-78. Available from: https://doi.org/10.1016/j.cpr.2015.03.001 
33. Harper S, McKinnon B. Global socioeconomic inequalities in tobacco use: internationally comparable estimates from the world health surveys. Cancer Causes Control [Internet]. 2012 [cited 2017 Dec 15];23 Suppl 1:11-25. Available from: https://doi.org/10.1007/ s10552-012-9901-5

34. Jones L, Bates G, McCoy E, Bellis MA. Relationship between alcohol-attributable disease and socioeconomic status, and the role of alcohol consumption in this relationship: a systematic review and meta-analysis. BMC Public Health [Internet]. 2015 [cited 2017 Dec 15];15:400. Available from: https://doi.org/10.1186/s12889-015-1720-7

35. Castillo-Carniglia Á, Kaufman JS, Pino P. Small area associations between social context and alcohol-attributable mortality in a middle income country. Drug Alcohol Depend [Internet]. 2014 [cited 2017 Dec 15];137:129-36. Available from: https://doi.org/10.1016/j. drugalcdep.2014.01.020

36. Daniel JZ, Hickman M, Macleod J, Wiles N, Lingford-Hughes A, Farrell M, Araya R, et al. Is socioeconomic status in early life associated with drug use? A systematic review of the evidence. Drug Alcohol Rev [Internet]. 2009 [cited 2017 Dec 15];28(2):142-53. Available from: https:// doi.org/10.1111/j.1465-3362.2008.00042.x

37. Yamamura M, Santos Neto M, Chiaravalloti Neto F, Arroyo LH, Ramos ACV, de Queiroz AAR, et al. Areas with evidence of equity and their progress on mortality from tuberculosis in an endemic municipality of southeast Brazil. Infect Dis Poverty [Internet]. 2017 [cited 2017 Dec 15];6(1):134. Available from: https://doi.org/10.1186/s40249-017-0348-5

38. Kaner EF, Dickinson HO, Beyer F, Campbell F, Schlesinger C, Heather N, et al. Effectiveness of brief alcohol interventions in primary care populations. Cochrane Database Syst Ver [Internet]. 2007 [cited 2017 Dec 15];(2):CD004148. Available from: https://doi. org/10.1002/14651858.CD004148.pub3

39. Probst C, Roerecke M, Behrendt S, Rehm J. Socioeconomic differences in alcohol-attributable mortality compared with all-cause mortality: a systematic review and meta-analysis. Int J Epidemiol [Internet]. 2014 [cited 2017 Dec 15];43(4):1314-27. Available from: https://doi. org/10.1093/ije/dyu043

40. Clement S, Schauman O, Graham T, Maggioni F, Evans-Lacko S, Bezborodovs N, et al. What is the impact of mental health-related stigma on help-seeking? A systematic review of quantitative and qualitative studies. Psychol Med [Internet]. 2015 [cited 2017 Dec 15];45(1):11-27. Available from: https://doi.org/10.1017/S0033291714000129

41. Faggiano F, Minozzi S, Versino E, Buscemi D. Universal school-based prevention for illicit drug use. Cochrane Database Syst Rev [Internet]. 2014 [cited 2017 Dec 18];(12):CD003020. Available from: https://doi.org/10.1002/14651858.CD003020.pub3

42. Mhimbira FA, Cuevas LE, Dacombe R, Mkopi A, Sinclair D. Interventions to increase tuberculosis case detection at primary healthcare or community-level services. Cochrane Database Syst Rev [Internet]. 2017 [cited 2017 Dec 15]; 11:CD011432. Available from: https://doi. org/10.1002/14651858.CD011432.pub2

43. Pinheiro PGOD, Sá LD, Palha PF, Oliveira RCC, Nogueira JA, Villa TCS. Critical points for the control of tuberculosis on primary health care. Rev Bras Enferm [Internet]. 2017 [cited 2017 Dec 15];70(6):1227-34. Available from: http://dx.doi.org/10.1590/0034-7167-2016-0467

44. Bender A, Guruge S, Hyman I, Janjua M. Tuberculosis and common mental disorders: international lessons for Canadian immigrant health. Can J Nurs Res [Internet]. 2012 [cited 2017 Dec 15];44(4):56-75. Available from: http://cjnr.archive.mcgill.ca/article/viewFile/2376/2370 